\title{
The Life of Benjamin Franklin volume 1
}




\section{Gune $2.1925^{\circ}$
elis
$34^{2}$}

thaving faliley beck

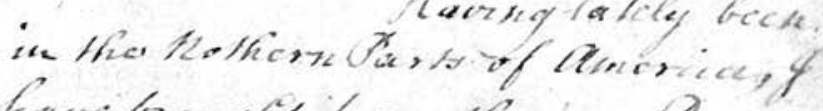

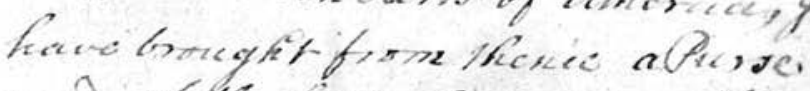

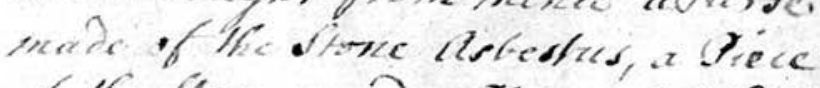

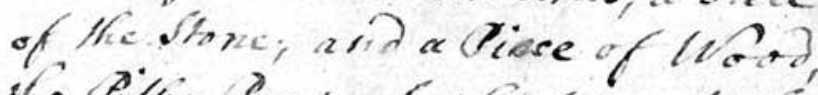
ite Pitriy Mar of nticek is of the same thatuse, deut caed by the $f_{m}=$

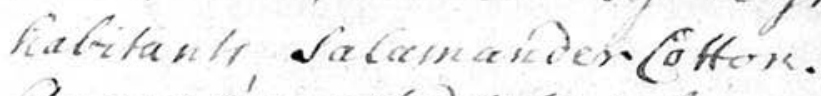
25 you a'se metcal to be a dowed

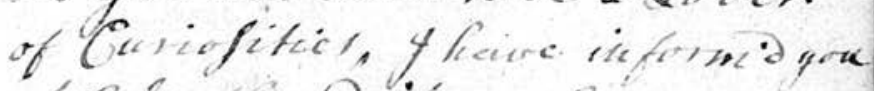
of Ange; a did if pouthere ariay fuckination le purthufethem, on des ewr, tet me kinomi youn. Alea =

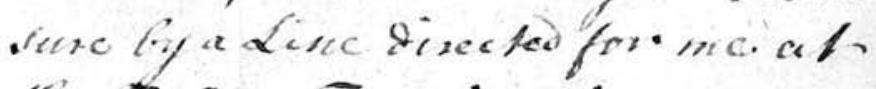
We Golden Fasi is ittle Brifxim, and froile wail upon you with thicil.

P. Fexpect to be f arr, ais.

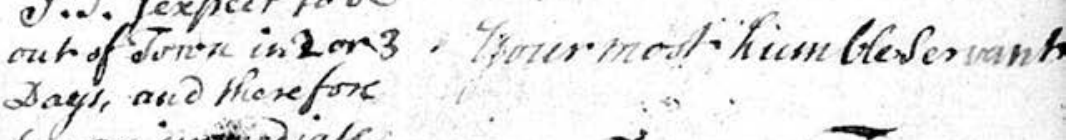
beyan insthodials "Qnsure?

Mcrianintoritilin 


\section{The Life of}

Benjamin Franklin

VOLUME 1

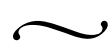

$\underset{1706-1730}{J o u r n a l i s t}$

J. A. Leo Lemay

$\overline{\text { PENN }}$

University of Pennsylvania Press

Philadelphia 
Copyright (C) 2006 University of Pennsylvania Press

All rights reserved

Printed in the United States of America on acid-free paper

$\begin{array}{lllllllll}10 & 9 & 8 & 7 & 6 & 5 & 4 & 3 & 2\end{array}$

Published by

University of Pennsylvania Press

Philadelphia, Pennsylvania 19104-4112

Text design by Pat Callahan

Library of Congress Cataloging-in-Publication Data

Lemay, J. A. Leo (Joseph A. Leo), 1935-

The life of Benjamin Franklin / J. A. Leo Lemay.

p. $\mathrm{cm}$.

Includes bibliographical references and index.

Contents: v. 1. Journalist, 1706-1730

ISBN 0-8122-3854-o (v. 1 : acid-free paper)

1. Franklin, Benjamin, 1706-1790. 2. Statesmen-United States-Biography.

3. Scientists-United States-Biography. 4. Inventors-United States-Biography.

5. Printers-United States-Biography. I. Title.

E302.6.F8L424 2005

$973.3^{\prime} 092-\mathrm{dc} 22$

[B]

2004063130

Front end papers: Franklin's Boston, drawn by Nian-Sheng Huang, based on John Bonner's map of Boston (1722).

Frontispiece: Franklin's first extant letter, written at age nineteen, to Sir Hans Sloane, founder of the British Museum, 2 June 1725. As Franklin remembered the event in 1771, Sloane (1660-1753) heard of Franklin's purse made of asbestos, "came to see me, and invited me to his House in Bloomsbury Square; where he show'd me all his Curiosities, and persuaded me to let him add that to the Number, for which he paid me handsomely" (A 44). Though Franklin recalled the event incorrectly, the meeting with the great naturalist Sloane was important enough for him to mention forty-six years later. The letter documents Franklin's early interest in natural philosophy. He later experimented with making paper from asbestos.

The ink's absorption into the paper reveals that Franklin wrote this letter on inexpensive stationery. In comparison to the promissory note of 5 May 1724, the handwriting is relatively graceful, though not so beautiful as Franklin's later holograph. Not only did Franklin evidently try to write a better hand in his letter to Sloane in 1725 than he had in his promissory note of the year before, but a comparison of the handwriting in this letter with the penmanship of the promissory note (Figure 20) and with handwriting in the epitaph (Figure 22, written much later) shows that as a young adult Franklin practiced and improved his handwriting. His early signature used the full name and often had a flourish underneath; the later ones generally used simply "B. Franklin," with a less ornate flourish or none.

Back end papers: Franklin's London, 1725-26. John Strype's map in John Stow, A Survey of the Cities of London \& Westminster (1720). Courtesy, Huntington Library. Locations supplied by Marina Fedosik. 
The biography as a whole is dedicated to

Ann C. Lemay, John C. Lemay, Lee C. Lemay, and Kate C. Lemay.

Volume 1 is dedicated to a number of Franklin scholars who are slightly my senior, who are in most cases good friends, and from all of whom I have learned greatly: A. Owen Aldridge, Whitfield J. Bell, Jr., I. Bernard Cohen, Claude-Anne Lopez, C. William Miller, Robert H. Newcomb, Edwin Wolf 2nd, and P. M. Zall. 
This page intentionally left blank 